\title{
Mooren's ulcer a rare cause of peripheral ulcerative keratitis
}

\author{
Mohta A. ${ }^{1}$, Sabnis M. ${ }^{2}$, Kalaria H. ${ }^{3}$, Nayyar M. ${ }^{4}$ \\ ${ }^{1}$ Dr. Antariksh Mohta, $3^{\text {rd }}$ Year Resident, ${ }^{2}$ Dr. Milind Sabnis, Professor \& Head of The Department, ${ }^{3}$ Dr. Hardik Kalaria, \\ $2^{\text {nd }}$ Year Resident, ${ }^{4}$ Dr. Monica Nayyar, $3{ }^{\text {rd }}$ Year Resident, all authors are affiliated with department of Ophthalmology at \\ Dr. D.Y.Patil Medical College Hospital \& Research Institute, Kolhapur, Maharashtra, India
}

Corresponding Author: Dr. Antariksh Mohta, $3^{\text {rd }}$ Year Resident, Department of Ophthalmology at Dr. D.Y. Patil Medical College Hospital \& Research Institute, Kolhapur, Maharashtra, India. E-mail id- antarikshmohta@gmail.com

\begin{abstract}
Authors report a rare cause of peripheral ulcerative keratitis. Mooren's ulcer is a chronic, painful, relentless ulcerative peripheral keratitis that begins from periphery of cornea near limbus as narrow crescent corneal infiltrate which then progresses circumferentially and centrally. Mooren's ulcer gets misdiagnosed as peripheral bacterial ulcer or another non-infective peripheral ulcerative keratitis.
\end{abstract}

Keywords: Mooren's ulcer, Peripheral ulcerative keratitis, Autoimmune

\section{Introduction}

Mooren's corneal ulcer was first described by Bowman in 1849 [1]. McKenzie described it as chronic serpiginous ulcer of cornea or ulcusrodens [2]. Authors here would like to report a rare cause of Peripheral Ulcerative Keratitis - Mooren's ulcer in a 34 year old male patient with no systemic diseases. Patient typically presented with complaint of ocular pain andulcer at peripheral cornea andcharacteristically hadoverhanging lip of the margin involved only anterior corneal layers in both eyes[3]. Mooren's ulcer is an idiopathic condition with no other related systemic disease. It is an autoimmune disease in which antibodies are directed to corneal stroma [4]. Usually Mooren's ulcer are misdiagnosed and wrongly treated, knowledge of which will help to differentiate and diagnose from other causes of peripheral ulcerative keratitis like infective keratitis, Pellucid and Terriens marginal degeneration etc and correct intervention can be done.

\section{Case Report}

A 34 years old male came to Dr D.Y. Patil Medical College, Hospital and Research Institute, Kolhapur Ophthalmology OPD with complaint of pain in both eyes since last 2 months.

Patient was apparently alright 2 months back when he started complaining of pain and foreign body sensation, photophobia in right eye which was associated with clear watery discharge. Patient then went to local doctor who prescribed oral analgesics and topical antibiotics. The symptoms were not resolved.

After 1 month he developed similar complaints in the left eye. Patient then continued using the same eye drops. After 2 months patient complained of severe pain in both eyes for which he came to our ophthalmology OPD. He gave no history for blunt trauma, chemical injury, skin rashes or vesicles over face or any other body part, or joint pains. He got operated for cataract surgery 3 years back in both eyes. Patient had no systemic diseases.

Following were the slit lamp examination findings:

$>$ Right eye was pseudophakic with BCVA of $6 / 24$, with normal lids, mild circum-corneal congestion, normal sclera \& iris, anterior chamber was showing no reaction.

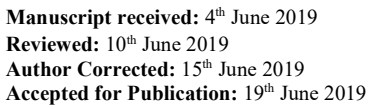




\section{Case Report}

Cornea showed a peripheral ulcerinferiorly from 4 o'clock to $80^{\prime}$ 'clock. Ulcer was progressive and crescentic in shape. It was extensively undermined with over hanging edge. It showed stromal melting. There was no clear zone between ulcer and the limbus. Thinned, scarred and vascularized cornea was seen inferiorly from where the ulcer must have initially progressed (Fig 1and 2)

$>$ Left eye was also pseudophakic with BCVA of 6/18, normal lids, sclera, iris and anterior chamber with mild circumcorneal congestion.

Cornea showed a peripheral ulcer inferiorly from 5 o'clock to 9 o'clock. It was centrally more progressive and crescentic in shape. Ulcer was similarly undermined with over hanging edge with less stromal melting and thinning. There was no clear zone between ulcer and the limbus. (Fig 3 and 4)

Investigations were done which showed normal haemoglobin, RBC, WBC and ESR.

Patient showed negative serology for VDRL (suspecting syphilis), RA factor (rheumatoid arthritis), ANA (systemic lupus erythematous), Hepatitis C. Liver and Renal FunctionTest reports were normal. For our patient conjunctival recession under local anesthesia was done, 2 clock hours on either side of the ulcer $\& 4 \mathrm{~mm}$ posterior to corneoscleral limbus \&post-operatively prednisolone acetate $1 \%$ every hourly and topical antibiotic were started to prevent secondary infection. On follow up ulcer showed healing with no progression but no improvement in vision due to corneal scarring.

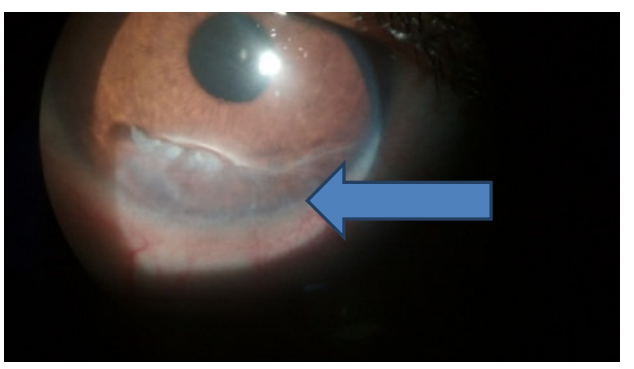

Fig-1: Right eye on slit lamp with diffuse illumination showing ulcer in inferior margin of cornea

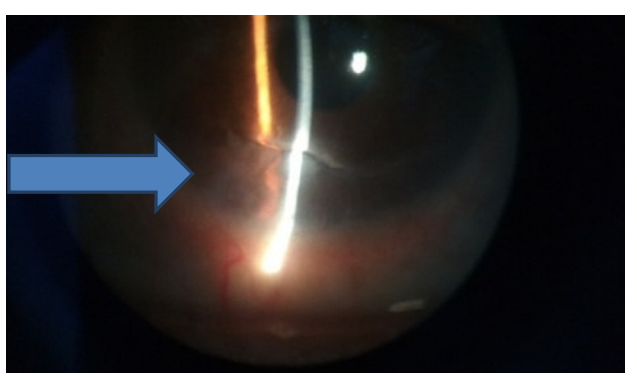

Fig-2: Right eye on slit lamp with parallelepiped illumination showing undermined ulcer with over hanging edge.

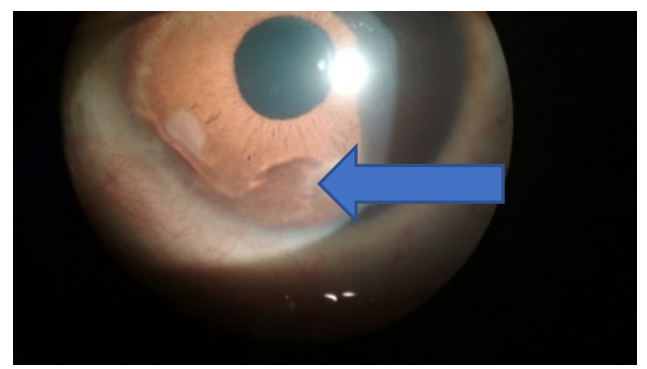

Fig 3: Left eye on slit lamp examination with diffuse illumination showing ulcer in the inferior margin of cornea. 


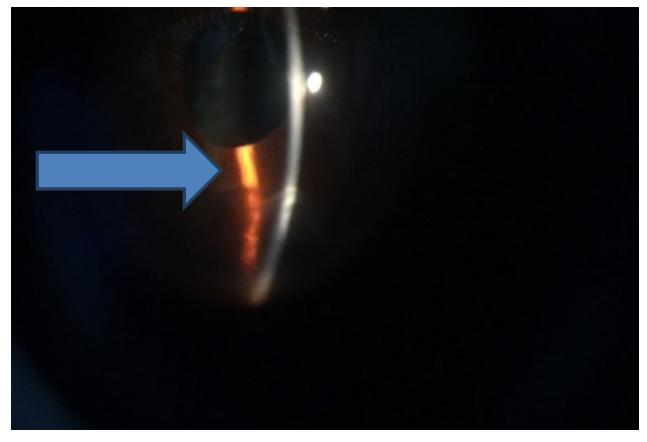

Fig 4: Left eye on slit lamp examination with parallelepiped illumination showing undermined ulcer with over hanging edge.

\section{Discussion}

Mooren's ulcer is rare conditions mostly seen in adult with no systemic diseases but has also been observed in children [5,6]. Most commonly found in Nigerian young men [7].

Wood and Kaufman have classifiedulcers [8].

- Type I is typical or benign Mooren'sulcer, unilateral with mild to moderate symptoms, responding well to medical and surgical treatment occurring in older patients.

- Type II is atypicalormalignant Mooren'sulcer, bilateral in $75 \%$ of cases, with severe pain and more symptoms. It does not respond well to therapy and usually occurring in younger patients [9].

Mooren's ulcer association with helminth, hepatitis C infection, herpes simplex, zoster, syphilis, tuberculosis, trauma, foreign body, chemical burns, and also after cataract, penetrating keratoplasty and lamellar keratoplasty like surgical procedure $[10,11]$.

Exact pathophysiology of Mooren's ulcer is unknown but pathological examination of involved area shows plasma cells, neutrophils, mast cells, eosinophils which support the autoimmune theory [12]. Schaap and his colleagues found circulating $\operatorname{IgG} \& \operatorname{IgA}$ antibodies in corneal and conjunctival epithelium cells using indirect immune fluorescent technique [13]. Martin and colleagues suggested that any infection, trauma or systemic disease can cause alteration of corneal antigen [14].

Mooren's ulcer patient complains of pain which is associated with redness, watering, photophobia and diminution of vision due to corneal opacity, irregular astigmatism and iritis. Ulceration begins from the periphery that is from limbus then it spread towards the center of the cornea. There is involvement of the stroma of cornea which leads to overhanging of edges of the ulcer which is characteristic of Mooren's ulcer. It may be associated with iritis, glaucoma, cataract rarely ulcer perforates [15]. Mooren's ulcer can be identified by detailed medical history and various laboratory investigations like complete blood count, erythrocyte sedimentation rate, rheumatoid factor, compliment fixation, antinuclear antibodies, anti-neutrophil cytoplasmic antibodies, circulating immune complexes, liver function tests, renal function test, tests to find treponemal infection like VDRL test, urine analysis with microscopy, chest X-ray.

Topical steroidal therapy is started with prednisolone acetate or phosphate \& topical antibiotic to prevent secondary infection and cycloplegics are also added [16]. This topical therapy can be supplemented with systemic steroids like prednisolone is started if topical steroids are ineffective after 7-10 days, deep infiltrating ulcer [17]. Therapeutic bandaging contact lens will be useful as it prevents perforation.

Eyedrop of Interferon alpha are made by diluting injectable recombinant IFN-2 alpha with preservativefree balanced salt solution. Its concentration is one million international units per $\mathrm{ml}$. It can be given as 2 hourly for first week. Systemic immunosuppressive can also be used, commonly used are cyclophosphamide, methotrexate, azathioprine. Recently cyclosporine, a drug is used, it helps to reduce helper $\mathrm{T}$ cell population and it stimulates suppressor $\mathrm{T}$ cell which retards the disease progression [18].

Conjunctival recession can also be doneunder topical orsubconjunctival anesthesia. Conjunctival excision is done with bare sclera technique. Superficial lamellar keratectomy, partial penetrating keratoplasty can be done to hold the inflammatory process. Perforation is treated with tissue adhesives. 


\section{Conclusion}

Conjunctival recession with topical corticosteroid and antibiotic eye drops showed healing of the ulcer in our patientwhich is an age old technique and may even show failure to heal the ulcer. Further studies are required for reliability and effectiveness of new treatments to avoid surgical intervention.

Funding: Nil, Conflict of interest: Nil Permission from IRB: Yes

\section{References}

1. Tabbara KF. Mooren's ulcer. Int Ophthalmol Clin. 1986 Winter; 26(4):91-8.

2. Mckenzie H. Disease of the Eye. 1854.p 631.

3. Myron Y, Jay SD. Ophthalmology. $4^{\text {th }}$ edition. China: Elsevier sunders; 2014.

4. Brad B. Kanski's clinical ophthalmology a systematic approach. $8^{\text {th }}$ edition. China: Elsevier's; 2016.

5. Nettleship, E. Chronic Serpiginous Ulcer of the Cornea (Mooren's Ulcer).Trans Ophthal Soc UK.1902; 22: 103-115.

6. Hogan, M.J, Zimmerman, L.E. Ophthal- mic Pathology, edition 2, Philadelphia: W. B. Saunders Co; 1962.

7. Majekodunmi AA. Ecology of Mooren's ulcer in Nigeria. Doc Ophthalmol. 1980 Oct 15;49(2):211-9.

8. Wood TO, Kaufman HE. Mooren's ulcer. Am J Ophthalmol. 1971 Jan;71(1 Pt 2):417-22.

9. Lewallen S, Courtright P. Problems with current concepts of the epidemiology of Mooren's corneal ulcer. Ann Ophthalmol. 1990 Feb;22(2):52-5.
10. Wilson SE, Lee WM, Murakami C, et al. Moorentype hepatitis C virus-associated corneal ulceration. Ophthalmology. 1994 Apr;101(4):736-45.

11. Mondino BJ, Hofbauer JD, Foos RY. Mooren's ulcer after penetrating keratoplasty. Am J Ophthalmol. 1987 Jan 15;103(1):53-6.

12. Brown SI. Mooren's ulcer. Histopathology and proteolytic enzymes of adjacent conjunctiva. $\mathrm{Br} \mathrm{J}$ Ophthalmol. 1975 Nov;59(11):670-4. DOI:10.1136/bjo. 59.11.670

13. Schapp OL, Feltkemp TE, Breebart AC: Circulating antibodies to corneal tissue in a patient suffering from Mooren's ulcer (ulcusrodens cornea).Clin Exp Immunol. 1969;5:365-370.

14. Martin NF, Stark WJ, Maumenee AE. Treatment of Mooren's and Mooren's-like ulcer by lamellar keratectomy: report of six eyes and literature review. Ophthalmic Surg. 1987 Aug;18(8):564-9.

15. Kietzman B. Mooren's ulcer in Nigeria. Am J Ophthalmol. 1968 May;65(5):679-85.

16. Donzis PB, Mondino BJ. Management of noninfectious corneal ulcers. Surv Ophthalmol. 1987 Sep-Oct; 32(2):94-110.

17. Ferguson EC 3rd, Carreno OB. Mooren's ulcer and delimiting keratotomy. South Med J. 1969 Oct;62 (10): 1170-4.

18. Wakefield D, Robinson LP. Cyclosporin therapy in Mooren's ulcer. Br J Ophthalmol. 1987 Jun;71(6):415-7.

\section{How to cite this article?}

Mohta A, Sabnis M, Kalaria H, Nayyar M. Mooren's ulcer a rare cause of peripheral ulcerative keratitis.Trop J Ophthalmol Otolaryngol.2019;4(2):170-173.doi:10.17511/jooo.2019.i02.17 